\title{
Fear of Success and Life Satisfaction in terms of Self-efficacy
}

\author{
Hasan Yılmaz \\ Department of Educational Sciences, Faculty of Literature, Kyrgyzstan Turkey Manas University, Kyrgyzstan
}

Copyright $\bigcirc 2018$ by authors, all rights reserved. Authors agree that this article remains permanently open access under the terms of the Creative Commons Attribution License 4.0 International License

\begin{abstract}
The purpose of the present research is presenting the relationships between self-efficacy, fear of success and life satisfaction; and determining the predictive power fear of success and self-efficacy on life satisfaction. For this purpose, self-efficacy, fear of achievement and life satisfaction scales were implemented on 625 individuals. In the analysis of the data, t-test and regression analysis were utilized. According to the findings of the research, there is a negative correlation between self-efficacy and fear of achievement. There is a relationship between all subscales of self-efficacy and fear of success. In particular, the "starting behavior" and "maintaining behavior" subscales are the strongest predictors of fear of success. Similarly, there is a positive correlation between self-efficacy and life satisfaction; and a significant negative correlation between fear of success and life satisfaction. Taken that self-efficacy is influenced by fear of success and fear of success and self-efficacy has effects on life satisfaction into consideration; any kind of psychological help for reducing the fear of success will increase self-efficacy. Similarly, any effort to improve self-efficacy will reduce fear of success. The increase in self-efficacy perceived positively and the decrease in fear of success will increase the individual's life satisfaction.
\end{abstract}

Keywords Fear of Success, Life Satisfaction and Self-efficacy

\section{Introduction}

Self-efficacy is related with a strong sense of personal efficacy, better health, higher success and creativity, and better social integration. Self-efficacy is about whether an action is to be started and how much effort will be paid and how much struggle will put against obstacles and failures. In other words, self-efficacy is not a concept related to our abilities and technical skills, but it is a concept related to the perception whether we can reach our goals. According to Bandura [1] self-efficacy makes a difference in the way people think, feel and behave. Low self-efficacy is associated with depression, anxiety, and despair.
Individuals with lower self-efficacy also have lower self-esteem and they have pessimistic thoughts about their achievements and personal growth. People with high selfefficacy are willing and creative in performing more challenging tasks. Higher self-efficacy also enables to choose challenging goals, explore the environment and take advantage of environmental conditions. Self-efficacy is not a skill; it is the belief on what the individuals can do in accordance with their abilities. Self-efficacy is much more than the intention of the individual to achieve an aim, since it is the sum of beliefs about starting, maintaining, concluding, and even more importantly, struggling with the obstacles that will face in this process. In short, self-efficacy belief is an individual's belief that they can perform the behavior that produces the result [2].

The fear of success can be regarded as the counter concept of self-efficacy. It can be defined as the behaviors of avoiding success resulting from the anxieties of that those who overwork are negatively evaluated, the works of very successful individuals are sabotaged by others, and so resulting in the formation of low goals, the tendency towards easy tasks, the diminution of attainment with the worry that the interpersonal relations of highly successful people are interrupted. Fear of success is important in terms of explaining the obstructive attitudes. Fear of negative outcomes of success is the most important determinant in the emergence of fear of success [3]. Individuals who perceive the consequences of being successful as a threat reveal fear of success as a result of the anxiety to confront this threat [4]. Fear of success was first coined by Horner in the late 1960s [5]. In an article published in 1974, Horner argued that the sense of raising children, which is manifested by an extreme competition-based lifestyle, augments and fuels fear of success. On the other hand, cognitive approaches explain avoiding success as a learned response, which is presented by people who are successful at a socially unacceptable level and they argued that this turns into a role and habit learned from other people [6]. According to the reconciliation approach, fear of success emerges with a sense of avoiding success and stems from an effort to reach a compromise between conflicting goals [7]. There are also studies in the related literature that 
describe fear of success as a type of anxiety. Researchers with this view preferred the concept of "The Impact of Negative Consequences of Success" instead of the concept of fear of success and started studies on developing scales accordingly [8], [9].

The concept of life satisfaction, first coined by Neugarten in 1961, is the result or situation obtained by comparing what a person expects and what they have [10]. Life satisfaction represents the cognitive direction of subjective well-being from concepts related to human happiness. Subjective well-being is defined as cognitive and emotional evaluation of a person's life. This evaluation includes the emotional response to the events and the cognitive assessment of satisfaction. When people feel many pleasant and unpleasant emotions, when they are involved in engaging activities, experience too much joy and too little pain and when they are satisfied with the lives, they experience a high level of subjective well-being. The subjective well-being focuses on self-assessment of one's life. Life satisfaction is defined as the general assessment of the quality of life according to the self-chosen criteria. Life satisfaction includes the satisfaction of the present life, the desire to change life, the satisfaction of the past, the satisfaction of the future and the opinion of the person's relatives about that person's life. Satisfaction areas may include work, family, leisure time, health, money, self and person's immediate surroundings [11] (Dost, M. T. 2007: 2).

To summarize the explanations on self-efficacy, fear of success and life satisfaction provided so for; self-efficacy is the belief that one has the necessary skills to perform an aim [1]. Fear of success can be defined as the behaviors of avoiding success resulting from the anxieties of that those who overwork are negatively evaluated, the works of very successful individuals are sabotaged by others, and so resulting in the formation of low goals, the tendency towards easy tasks, the diminution of attainment with the worry that the interpersonal relations of highly successful people are interrupted. Life satisfaction is an element related to the individual's general feeling of well-being. Life satisfaction is, besides being related to quality of life, not a concept that is enough to explain all life quality and life satisfaction. It is believed that self-efficacy and life satisfaction are effective in determining the life goals of the individual and in reaching these goals. Although self-efficacy and life satisfaction seem to be two sources supporting and feeding each other, fear of success is a pressure and threat to both. Accordingly, the purpose of the present research is to reveal the relation between these three variables and their power of influence on each other. We hope that the findings will provide important insights into any kind of psychological support studies on improving the quality of life.

The main purpose of the present research is to reveal the relationship between self-efficacy, fear of success and life satisfaction; and determining the predictive power of self-efficacy on fear of success and fear of success and self-efficacy on life's satisfaction.

\section{Materials and Methods}

Relational screening model was adopted in the present research. Data collection tools prepared for this purpose were applied on 625 subjects. Among the universe of the research, 295 current students in the psychological counseling and guidance departments, and 330 individuals who have graduated from this department were reached.

\subsection{Data Collection Tools}

Three different data collection tools were used in the present research. The first is the Self-Efficacy-Competence Scale (SESS) developed by Sherrer et al [12] and adapted to Turkish by Gözüm and Aksayan [13]. The scale consists of 23 items and has four sub-scales. These are initiating behavior, maintaining behavior, completing behavior and struggling with obstacles. The scale measures the general self-efficacy perception that is not specific to any specific domain. The Cronbach alpha internal consistency coefficient of the Turkish form of the scale was .81, and test-retest reliability was found as ,92 [13].

The second data collection tool used in the present research was the 21-item Fear of Success Scale developed by Hyland and Dann [7] and adapted to Turkish by Melli [14]. Correlations between item-total test scores of the Fear of Success Scale vary between .074 and .467 . The internal consistency coefficient was found as $\mathrm{r}=.72$. The scale has 4 subscales; Social Outcomes of Success, Negating Success, Internal Anxiety and Avoiding Success.

The third data collection tool used in the present research is "Life Satisfaction Scale" developed by Diener, Emmons, Larsen and Griffin [15]. The scale, which was adapted to Turkish by Dagli and Baysal [16], consists of 5 questions in one factor. The reliability of LSS was defined with the Cronbach Alpha consistency coefficient and the test-retest technique and internal consistency coefficient was calculated as $\mathrm{r}=0.88$ for the whole scale.

\subsection{Statistical Analysis}

In the analysis of the data; independent $t$ test was utilized to determine whether fear of achievement and self-efficacy perceptions varied by gender variable. The level of significance was taken as .05 . Linear regression analysis was utilized to determine the relationship and the level of prediction between the variables and sub-scales of the scales.

\section{Results}

Results obtained in the present research are presented in 
this part.

\subsection{The General Case on Self-efficacy}

The results of the descriptive analysis of the findings obtained from the self-efficacy scale are presented in Table 1. Taken that the maximum score of the scale was 110 and the arithmetic mean of the subjects was 83.68 into consideration; we can claim that the participants in the sample have a high level of self-efficacy. The proportion of the arithmetic average to the maximum score in terms of sub-scales; shows that the subjects have the highest self-efficacy in terms of completing the behavior and the lowest terms of struggling with obstacles. Additionally, the highest variability among the four subscales was in the response to the initiation behavior subscale $(\mathrm{s}=5,37)$ and the least variance was observed in the struggling with obstacles subscale (2.34).

\subsection{Analysis Results for Findings Descriptive Analysis}

Table 1. Descriptive Analysis of the Findings Obtained from the Self-Efficacy Scale

\begin{tabular}{|c|c|c|c|c|c|}
\hline $\begin{array}{c}\text { Sub-scales of } \\
\text { the } \\
\text { Self-efficacy } \\
\text { Scale }\end{array}$ & $\mathbf{N}$ & Min. & Max. & Mean & $\begin{array}{c}\text { Std. } \\
\text { Deviation }\end{array}$ \\
\hline $\begin{array}{c}\text { Initiating } \\
\text { Behaviour }\end{array}$ & 625 & 8,00 & 40,00 & 29,55 & 5,37 \\
\hline $\begin{array}{c}\text { Maintaining } \\
\text { Behaviour }\end{array}$ & 625 & 11,00 & 33,00 & 25,06 & 3,70 \\
\hline $\begin{array}{c}\text { Completing } \\
\text { Behaviour }\end{array}$ & 625 & 7,00 & 25,00 & 19,77 & 3,35 \\
\hline $\begin{array}{c}\text { Struggling } \\
\text { With } \\
\text { Obstacles }\end{array}$ & 625 & 3,00 & 15,00 & 9,30 & 2,34 \\
\hline $\begin{array}{c}\text { Self-Efficacy } \\
\text { Scale General }\end{array}$ & 625 & 37,00 & 110,00 & 83,68 & 11,90 \\
\hline
\end{tabular}

Table 2. Descriptive Analysis of the Findings Obtained from the Fear of Success Scale

\begin{tabular}{|c|c|c|c|c|c|}
\hline $\begin{array}{c}\text { Fear of } \\
\text { Success } \\
\text { Subscales }\end{array}$ & N & Minimum & Maximum & Mean & $\begin{array}{c}\text { Std. } \\
\text { Dev. }\end{array}$ \\
\hline $\begin{array}{c}\text { Social } \\
\text { outcomes } \\
\text { of } \\
\text { Success }\end{array}$ & 625 & 7,00 & 35,00 & 25,72 & 5,73 \\
\hline $\begin{array}{c}\text { Negating } \\
\text { Success }\end{array}$ & 625 & 7,00 & 35,00 & 15,43 & 4,88 \\
\hline $\begin{array}{c}\text { Internal } \\
\text { Anxiety }\end{array}$ & 625 & 4,00 & 20,00 & 10,75 & 3,53 \\
\hline $\begin{array}{c}\text { Avoiding } \\
\text { Success }\end{array}$ & 625 & 3,00 & 15,00 & 7,12 & 2,83 \\
\hline $\begin{array}{c}\text { Fear of } \\
\text { Success } \\
\text { Scale } \\
\text { General }\end{array}$ & 625 & 21,00 & 105,00 & 59,03 & 9,48 \\
\hline
\end{tabular}

\subsection{Findings Related to the Prediction of Self-efficacy Perception of Fear of Success}

Findings related to the extent to which self-efficacy perception predicts fear of success are presented in Table 3.

As presented in Table 3; self-efficacy generally explains the $11 \%$ of fear of success $\left(F=19.488 ; \mathrm{R}^{2}=0.11\right.$; $\mathrm{p}=0.001$ ). There is a significant correlation between all sub-scales of self-efficacy and fear of achievement at .05 level. There is a negative correlation between completing the behavior and the struggling with obstacles subscales of self-efficacy and fear of success. There is a weak positive relationship between the completing the behavior and the struggling with obstacles subscales and the fear of success. In terms of self-efficacy predicting the fear success, initiating behavior subscale is ranked first among the four subscales of self-efficacy. This is respectively followed by completing the behavior, maintaining behavior, and struggling with obstacles.

Table 3. Results of the Analysis on the Prediction of Perception of Self-efficacy of the Fear of Success

\begin{tabular}{|c|c|c|c|c|c|c|c|}
\hline Self-efficacy Subscales & B & $\mathrm{SH}_{\mathrm{B}}$ & $\beta$ & $\mathbf{t}$ & $\mathbf{p}$ & $\mathbf{R}$ & Partial $\mathbf{r}$ \\
\hline (Constant) & 68,108 & 2,672 & & 25,489 &, 001 & & \\
\hline Initiating Behaviour &,- 491 & ,097 &,- 278 & $-5,071$ &, 001 &,- 242 &,- 200 \\
\hline Maintaining Behaviour &,- 370 & ,139 &,- 145 & $-2,661$ &, 008 &,- 205 &,- 106 \\
\hline Completing Behaviour &, 500 &, 142 &, 177 & 3,528 &, 000 &, 031 &, 140 \\
\hline $\begin{array}{l}\text { Struggling With } \\
\text { Obstacles }\end{array}$ &, 518 & ,184 &, 128 & 2,821 &, 005 & ,072 &, 113 \\
\hline
\end{tabular}




\subsection{Findings Related to the Prediction of Self-proficiency Perception of Social Outcomes of Success Subscale of Fear of Success}

The findings related to the prediction of self-efficacy perception of "Social outcomes of Success" subscale are presented in Table 4. As presented in Table 4, self-efficacy explains the $7 \%$ of "social outcomes of success" subscale of fear of success $\left(\mathrm{F}=12.399, \mathrm{R}^{2}=0.07, \mathrm{p}=0.001\right)$. There is a significant correlation between maintaining behavior and completing behavior subscales of self-efficacy and fear of success at .05 level. There was no significant relationship between the initiating the behavior and the struggling with obstacles subscales and fear of success. In terms of self-efficacy predicting the social outcomes of success subscale of fear success, completing behavior subscale is ranked first among the four subscales of self-efficacy. This is respectively followed by maintaining behavior, initiating the behavior, and struggling with obstacles subscales.

\subsection{Findings Related to the Prediction of Self-proficiency Perception of Negating Success Subscale of Fear of Success}

The findings related to the prediction of self-efficacy perception of "Negating Success" subscale are presented in Table 5.

As presented in Table 5, self-efficacy explains the 16\% of "negating success" subscale of fear of success ( $\mathrm{F}=28.74$; $\left.\mathrm{R}^{2}=0.16 ; \mathrm{p}=0.001\right)$. There are significant negative correlations between all subscales of self-efficacy and negating success subscale fear of success at .05 level. This finding suggests that negating success decreases at the extent that perceptions are positive in four subscales of self-efficacy; from another perspective that as negating success decreases self-efficacy sub-scale scores increase. In terms of self-efficacy predicting the negating success subscale of fear success, initiating the behavior subscale is ranked first among the four subscales of self-efficacy. This is respectively followed by maintaining behavior, struggling with obstacles subscales and completing the behavior subscales.

Table 4. Results of the Analysis on the Prediction of Perception of Self-Efficacy of the "Social outcomes of Success" subscale of Fear of Success

\begin{tabular}{|c|c|c|c|c|c|c|c|}
\hline Self-efficacy Subscales & $\mathbf{B}$ & $\mathbf{S H}_{\mathbf{B}}$ & $\boldsymbol{\beta}$ & $\mathbf{t}$ & $\mathbf{p}$ & $\mathbf{R}$ & Partial r \\
\hline (Constant) & 14,553 & 1,648 & & 8,829 &, 000 & & \\
\hline Initiating Behaviour &, 077 &, 060 &, 073 & 1,297 &, 195 &, 217 &, 052 \\
\hline Maintaining Behaviour &, 141 &, 086 &, 091 & 1,642 &, 009 &, 221 &, 066 \\
\hline Completing Behaviour &, 269 &, 087 &, 158 & 3,082 &, 002 &, 241 &, 123 \\
\hline Struggling With Obstacles &, 003 &, 113 &, 001 &, 026 &, 979 &, 145 &, 001 \\
\hline \multicolumn{7}{|c|}{$\mathrm{R}=0.27, \mathrm{R}^{2}=0.07, \mathrm{~F}=12.399, \mathrm{p}=0.001$} \\
\hline
\end{tabular}

Table 5. Results of the Analysis on the Prediction of Perception of Self-Efficacy of the "Negating Success" subscale of Fear of Success

\begin{tabular}{|c|c|c|c|c|c|c|c|}
\hline Self-efficacy Subscales & B & $\mathbf{S H}_{\mathrm{B}}$ & $\boldsymbol{\beta}$ & $\mathbf{t}$ & $\mathbf{p}$ & $\mathbf{r}$ & Partial $\mathbf{r}$ \\
\hline (Constant) & 25,806 & 1,341 & & 19,238 &, 000 & & \\
\hline Initiating Behaviour &,- 251 & 049 &,- 276 & $-5,172$ &, 000 &,- 348 &,- 203 \\
\hline Maintaining Behaviour &,- 266 & 070 &,- 202 & $-3,817$ &, 000 &,- 328 &,- 152 \\
\hline Completing Behaviour & 051 & 071 & ,035 & ,713 & ,476 &,- 132 & 029 \\
\hline Struggling With Obstacles & 293 & 092 &, 140 & 3,176 &, 002 &,- 012 & 127 \\
\hline \multicolumn{8}{|c|}{$\mathrm{R}=0.40, \mathrm{R}^{2}=0.16, \mathrm{~F}=28.74, \mathrm{p}=0.001$} \\
\hline
\end{tabular}




\subsection{Findings Related to the Prediction of Self-proficiency Perception of Internal Anxiety Subscale of Fear of Success}

The findings related to the prediction of self-efficacy perception of "Internal Anxiety" subscale are presented in Table 6.

As presented in Table 6, self-efficacy explains the 13\% of "internal anxiety" subscale of fear of success $(\mathrm{F}=22.639$; $\left.\mathrm{R}^{2}=0.13 ; \quad \mathrm{p}=0.001\right)$. There are significant negative correlations between all subscales of self-efficacy and internal anxiety subscale fear of success at .05 level. Likewise, this finding suggests that internal decreases at the extent that perceptions are positive in initiating, maintaining and completing the behavior and struggling with obstacles subscales of self-efficacy. In terms of self-efficacy predicting the internal anxiety subscale of fear success, initiating the behavior subscale is ranked first among the four subscales of self-efficacy. This is respectively followed by completing behavior, maintaining behavior and struggling with obstacles subscales.

\subsection{Findings Related to the Prediction of Self-proficiency Perception of Avoiding Success Subscale of Fear of Success}

The findings related to the prediction of self-efficacy perception of "Avoiding Success" subscale are presented in Table 7.

As presented in Table 7, self-efficacy explains the 10\% of "avoiding success" subscale of fear of success $\left(\mathrm{F}=16.210 ; \quad \mathrm{R}^{2}=0.10 ; \mathrm{p}=0.001\right)$. There are significant negative correlations between initiating the behavior, maintaining the behavior and struggling with obstacles subscales of self-efficacy and internal anxiety subscale fear of success at .05 level. However, there are no significant relations between completing the behavior subscale of self-efficacy and avoiding success subscale of fear of success. This finding suggests that all subscales but completing the behavior subscale of self-efficacy are negatively correlated with avoiding success subscale of fear of success. In terms of self-efficacy predicting the avoiding success subscale of fear success, maintaining the behavior subscale is ranked first among the four subscales of self-efficacy. This is respectively followed by initiating the behavior and struggling with obstacles subscales.

Table 6. Results of the Analysis on the Prediction of Perception of Self-Efficacy of the "Internal Anxiety" subscale of Fear of Success

\begin{tabular}{|c|c|c|c|c|c|c|c|}
\hline Self-efficacy Subscales & B & $\mathbf{S H}_{\mathrm{B}}$ & $\boldsymbol{\beta}$ & $\mathbf{t}$ & $\mathbf{p}$ & $\mathbf{r}$ & Partial $\mathbf{r}$ \\
\hline (Constant) & 16,027 & ,986 & & 16,254 &, 000 & & \\
\hline Initiating Behaviour &,- 224 & ,036 &,- 341 & $-6,282$ &, 000 &,- 319 &,- 245 \\
\hline Maintaining Behaviour &,- 102 & 051 &,- 107 & $-1,995$ &, 046 &,- 251 &,- 080 \\
\hline Completing Behaviour &, 180 &, 052 &, 171 & 3,443 &, 001 &,- 044 & 137 \\
\hline Struggling With Obstacles & 039 & 068 &, 026 &, 574 &, 566 &,- 043 & 023 \\
\hline
\end{tabular}

Table 7. Results of the Analysis on the Prediction of Perception of Self-Efficacy of the "Avoiding Success" subscale of Fear of Success

\begin{tabular}{|c|c|c|c|c|c|c|c|}
\hline Self-efficacy Subscales & $\mathbf{B}$ & $\mathbf{S H}_{\mathbf{B}}$ & $\boldsymbol{\beta}$ & $\mathbf{T}$ & $\mathbf{p}$ & $\mathbf{r}$ & Partial r \\
\hline (Constant) & 11,722 &, 807 & & 14,528 &, 000 & & \\
\hline Initiating Behaviour &,- 093 &, 029 &,- 175 & $-3,170$ &, 002 &,- 250 &,- 126 \\
\hline Maintaining Behaviour &,- 142 &, 042 &,- 186 & $-3,383$ &, 001 &,- 255 &,- 135 \\
\hline Completing Behaviour &, 000 &, 043 &, 000 &,- 005 &, 996 &,- 101 &, 000 \\
\hline Struggling With Obstacles &, 183 &, 055 &, 151 & 3,305 &, 001 &, 023 &, 132 \\
\hline \multicolumn{7}{|c|}{$\mathrm{R}=0.31, \mathrm{R}^{2}=0.10, \mathrm{~F}=16.210, \mathrm{p}=0.001$} \\
\end{tabular}




\subsection{Findings Related to the Relationship between Success Fear, Self-efficacy Perception and Life Satisfaction}

One of the objectives of the present research is finding out whether fear of success and self-efficacy has any effects on life satisfaction. The findings of this analysis are presented in Table 8. As presented in Table 8, fear of success and self-efficacy perception together explain $14 \%$ of life satisfaction $\left(\mathrm{F}=49.982, \mathrm{R}^{2}=0.14, \mathrm{p}=0.001\right)$. While self-efficacy explains the $13 \%$ of this variation alone, this rate increases to $14 \%$ along with fear of success. There is a significant positive correlation between self-efficacy and life satisfaction at .01 level and there was a significant negative correlation between fear of success and life satisfaction at .01 level.

\subsection{Findings Related to the Relations between Self-efficacy Perception Subscales and Life Satisfaction}

Findings related to the relationships between self-efficacy perception and life satisfaction in terms of subscales are presented in Table 9. As presented in Table 9, the effective subscale of self-efficacy on life satisfaction is "initiating the behavior" subscale. Initiating the behavior subscale can explain the $9 \%$ of life satisfaction. This is followed by "Struggling with Obstacles" subscale.
Struggling with obstacles explains the $6.5 \%$ of life satisfaction. This is followed by completing the behavior subscale, while the relationship between maintaining the behavior subscale and life satisfaction isn't significant.

\subsection{Findings Related to the Relations between Fear of Success Subscales and Life Satisfaction}

Findings related to the relationships between fear of success and life satisfaction are presented in Table 10. Without self-efficacy, fear of success explains the $8 \%$ of variation in life satisfaction. In other words, $8 \%$ of life satisfaction can be explained by fear of success. When the table is studied in terms of sub-scales of fear of success; the relationships between three sub-scales of fear of success except for the "Social outcomes of Success" and life satisfaction are negative. Among the four sub-scales, the only sub-scale positively correlated with life satisfaction is the "Social Results of Success" subscale. Among the four subscales, only the "internal anxiety" sub-scale is significantly related with life satisfaction. The relationship between life satisfaction and internal anxiety subscale is significant at .01 level. In terms of fear of success predicting the life satisfaction, internal anxiety subscale is ranked first among the four subscales. This is respectively followed by "social outcomes of success", "avoiding success" and "internal anxiety".

Table 8. Analysis Results on ear of Success and the Self-Efficacy Predicting Life Satisfaction

\begin{tabular}{|c|c|c|c|c|c|c|c|}
\hline Self-efficacy Subscales & $\mathbf{B}$ & $\mathbf{S H}_{\mathbf{B}}$ & $\boldsymbol{\beta}$ & $\mathbf{t}$ & $\mathbf{p}$ & $\mathbf{r}$ & Partial r \\
\hline (Constant) & 14,675 & 2,063 & & 7,115 &, 000 & & \\
\hline Self-efficacy &, 156 &, 017 &, 343 & 9,125 &, 000 &, 359 &, 344 \\
\hline Fear of Success &,- 057 &, 022 &,- 101 & $-2,670$ &, 008 &,- 152 &,- 106 \\
\hline \multicolumn{7}{|c|}{$\mathrm{R}=0.37, \mathrm{R}^{2}=0.14, \mathrm{~F}=49.982, \mathrm{p}=0.001$} \\
\hline
\end{tabular}

Table 9. Findings related to the Self-Efficacy Perception Subscales Predicting Life Satisfaction

\begin{tabular}{|c|c|c|c|c|c|c|c|}
\hline Self-efficacy Subscales & $\mathbf{B}$ & $\mathbf{S H}_{\mathbf{B}}$ & $\boldsymbol{\beta}$ & $\mathbf{T}$ & $\mathbf{p}$ & $\mathbf{r}$ & Partial r \\
\hline (Constant) & 11,152 & 1,510 & & 7,387 &, 000 & & \\
\hline Initiating Behaviour &, 184 &, 055 &, 183 & 3,367 &, 001 &, 316 &, 134 \\
\hline Maintaining Behaviour &, 090 &, 079 &, 061 & 1,144 &, 253 &, 277 &, 046 \\
\hline Completing Behaviour &, 152 &, 080 &, 094 & 1,894 &, 049 &, 282 &, 076 \\
\hline Struggling With Obstacles &, 272 &, 104 &, 117 & 2,618 &, 009 &, 256 &, 105 \\
\hline \multicolumn{7}{|c|}{$\mathrm{R}=0.36, \mathrm{R}^{2}=0.13, \mathrm{~F}=23.416, \mathrm{p}=0.001$} \\
\end{tabular}

Table 10. Findings related to the Fear of Success Subscales Predicting Life Satisfaction

\begin{tabular}{|c|c|c|c|c|c|c|c|}
\hline Fear of Success Subscales & $\mathbf{B}$ & $\mathbf{S H}_{\mathbf{B}}$ & $\boldsymbol{\beta}$ & $\mathbf{T}$ & $\mathbf{p}$ & $\mathbf{~}$ & Partial r \\
\hline (Constant) & 27,080 & 1,416 & & 19,118 &, 000 & & \\
\hline Social outcomes of Success &, 049 &, 039 &, 062 & 1,514 &, 131 &, 058 &, 061 \\
\hline Negating Success &,- 005 &, 056 &,- 005 &,- 099 &, 921 &,- 130 &,- 004 \\
\hline Internal Anxiety &,- 419 &, 067 &,- 273 & $-6,232$ &, 000 &,- 267 &,- 243 \\
\hline Avoiding Success &, 051 &, 086 &, 027 &, 590 &, 556 &,- 070 &, 024 \\
\hline \multicolumn{7}{|c|}{$\mathrm{R}=0.27, \mathrm{R}^{2}=0.08, \mathrm{~F}=12.613, \mathrm{p}=0.001$} \\
\hline
\end{tabular}




\section{Discussion}

The present research has revealed that three variables (self-efficacy, fear of success and life satisfaction) interrelated. The relationship between self-efficacy and fear of success is negative. Although the present research doesn't directly address to self-efficacy and fear of success, the findings are in agreement with of some other studies. Many previous studies have reported negative relationships between low self-efficacy and low self-esteem, depression and despair [1]. The present research has found that there is a negative correlation between self-efficacy, especially its "initiating behavior" and "maintaining behavior" subscales and fear of success. Taken that "initiating behavior" is the first step of an act intended for a purpose, this finding has a logical basis. The fact that an individual who has fear of success avoids taking the first step on his path to success is particularly emphasized in the study conducted by Miller [4]. Similarly, it is known that many people fail to succeed in maintaining the behavior stage, even if they can manage initiating the behavior stage. In our daily lives, there are examples of many unfinished and quit tasks and acts. A significant and negative correlation between these two sub-scales of self-efficiency and fear of success is an important finding in this respect.

Since self-efficacy is defined as the belief that the individual can perform the behavior that produces the result [2]; it is possible to consider the fear of success as anxiety experienced due to the consequences of this belief, which reveals the relationship between self-efficacy perception and fear of success.

A similar interpretation can be provided for the relationship between fear of success and life satisfaction. According to the findings of the present research there is a correlation of -15 between fear of success and life satisfaction. $\mathrm{R}^{2}$ was calculated as 0.14 . This finding suggests that fear of success affects life satisfaction negatively. Taken O'Sullivan's [17] study revealing that hope is the best predictor of life satisfaction and that fear of success is a loss of hope in to consideration, the findings of the present research are in complete agreement with the findings of O'Sullivan.

A similar interpretation can be provided about the relationship between self-efficacy perception and life satisfaction. According to the findings of the present research there is a positive correlation of .36 between self-efficacy and life satisfaction. This finding is in agreement with many previous studies. A previous study by Vecchio et al. [18], reported that the strongest variable that predicted life satisfaction was the self-efficacy perception. The findings of the researches conducted by Caprara, G. V., Patrizia Steca [19] and Şahin [20] are also in agreement with the findings of the present research.

Additionally, another important finding of the present research is that "initiating behavior" sub-scale of self-efficacy is the strongest predictor of life satisfaction. The "internal anxiety" subscale is the strongest predictor of life satisfaction among the subscales of fear of success. When these two findings are taken together, we can mention the importance of "not being able to start behavior" that is resulted from internal anxiety for humans.

According to the findings of the present research, there is no significant difference across genders in terms of both the fear of success and self-efficacy perception. As mentioned in the literature review, there are a number of researches that report different findings on gender variable [21] (Condry and Dyer, 1976: 237-248). The fact that Stiver [22], in particular, reported no difference between women and men in terms of fear of success, is in complete agreement with the findings of the present research. On the other hand, there was a significant difference across genders in the subscale of "internal anxiety".

\section{Conclusions}

Consequently; the correlation values between the variables are low when the research results are generally evaluated. For this reason, data in our research provide limited information for psychotherapy and intervention. According to the findings that self-efficacy is affected by fear of success and fear of success and self-efficacy also have effects on life satisfaction; any kind of psychological help to reduce the fear of success will self-efficacy. Similarly, every effort to improve self-efficacy will reduce fear of success. The increase in self-efficacy perception and the decrease in fear of success will increase the individuals' life satisfaction.

\section{REFERENCES}

[1] A. Bandura. Self-efficacy: Toward a unifying theory of behavioral change. Psychological Review, Vol.84, 191-215, 1977.

[2] J. E. Maddux. Self-Efficacy: The Power of Believing You Can. Handbook of positive psychology. Oxford University Press, New York, p.2-3, 2000.

[3] C. Bauer, V. Friedrich, M. Wimber. Furcht vor Erfolg-Zusammenhang mit Sozialer Angst und Furcht vor Kritik [Fear of Success-Related with Social Anxiety and Fear of Criticism]. University of Regensburg, Regensburg, 2002.

[4] J. Miller. Fear of Success: Psychodynamic Implications. Journal of the American Academy of Psychoanalysis, Vol.22, No.1, 129-136, 1994.

[5] M. S. Horner. The measurement and behavior implications of fear of success in women. In: Motivation and Achievement. J. W. Atkinson, J. O. Raynor (eds.). Winston, 
Washington, DC, 1974.

[6] N. T. Feather, A. C. Raphelson. Fear of success in Australian and American student groups: Motive or Sex-Role Stereotype? Journal of Personality, Vol.42, 190-201, 1974.

[7] M. E. Hyland. There is No Motive to Avoid Success: The Compromise Explanation for Success-Avoiding Behavior. Journal of Personality, Vol.57, No.3, 665-693, 1989.

[8] K. R. Gelbort, J. L. Winer. Fear of success and fear of failure: A multitrait-multimethod validation study. Journal of Personality and Social Psychology, Vol.48, No.4, 1009-1014, 1985.

[9] S. Sadd, M. Leauner, P. Shaver, N. Dunivant. Objective Measurement of Fear of Success and Fear of Failure: A Factor Analytic Approach. Journal of Consulting and Clinical Psychology, Vol.46, No.3, 405-416, 1978.

[10] M. K. Özer. Yaşlılarda Yaşam Doyumu. Geriatri, Vol.6, No. 2, 72-74, 2003.

[11] M. Tuzgöl Dost. Examining Life Satisfaction Levels of University Students in Terms of Some Variables. Pamukkale University Journal of Education, Vol.22, No.2, 132-143, 2007.

[12] M. Sherer, J. E. Maddux, B. Mercandante, S. Prentice-Dunn, B. Jacobs, R. W. Rogers. The Self-efficacy Scale: Construction and validation. Psychological Reports, Vol.51, No.2, 663-671, 1982.

[13] S. Gözüm, S. Aksayan. Öz-etkililik-yeterlik ölçeği'nin Türkçe formunun güvenirlik ve geçerliği. Atatürk Üniversitesi Hemşirelik Yüksekoukul Dergisi, Vol.2, No.1, 21-34, 1999.

[14] Melli-Köktürk, A. S. (2000). Çok boyutlu Başarı Korkusu Ölçeği'nin Türkçe'ye uyarlanması ve başarı korkusu ile kendini kurgulama düzeyi arasındaki ilişki (Yüksek lisans tezi). Hacettepe Üniversitesi Sosyal Bilimler Enstitüsü, pp. 96-105, 2000.

[15] E. Diener, R. A. Emmons, R. J. Larsen, S. Griffin. The satisfaction with life scale. Journal of Personality Assessment, Vol.49, No.1, 71-75, 1985.

[16] A. Dağlı, N. Baysal. Adaptation of the Satisfaction With Life Scale into Turkish: The Study of Validity And Reliability. Electronic Journal of Social Sciences, Vol.15, No.59, 1250-1262, 2016.

[17] G. O'Sullivan. The Relationship between Hope, Eustress, Self-Efficacy, and Life Satisfaction among Undergraduates. Social Indicators Research. Vol.101, No.1, 155-172, 2011.

[18] G. M. Vecchio, M. Gerbino, C. Pastorelli, G. Del Bove, G. V. Caprara. Multi-faceted self-efficacy beliefs as predictors of life satisfaction in late adolescence. Personality and Individual Differences, Vol.43, 1807-1818, 2007.

[19] G. V. Caprara, P. Steca. Self-efficacy beliefs as determinants of prosocial behavior conducive to life satisfaction across ages. Journal of Social and Clinical Psychology, Vol.24, No.2, 191-217, 2005.

[20] D. Şahin. The investigation of teacher's self-compassion from the point of resilience and life satisfaction. Master of Science Thesis, Karadeniz Technical University, Trabzon, pp. 77-81, 2014.

[21] Orlofsky, J.L. A comparison of projective and objective fear-of-success and sex-role orientation measures as predictors of women's performance on masculine and feminine tasks. Sex Roles, Volume 7, Number 10, Page 999, 1981.

[22] S. B. Stiver. Fear of Success: A Motive to Avoid Success or a Response to Violation of Sex-Role Prescriptions? Doctoral Dissertation, Washington University, pp. 145-148, 1977. 